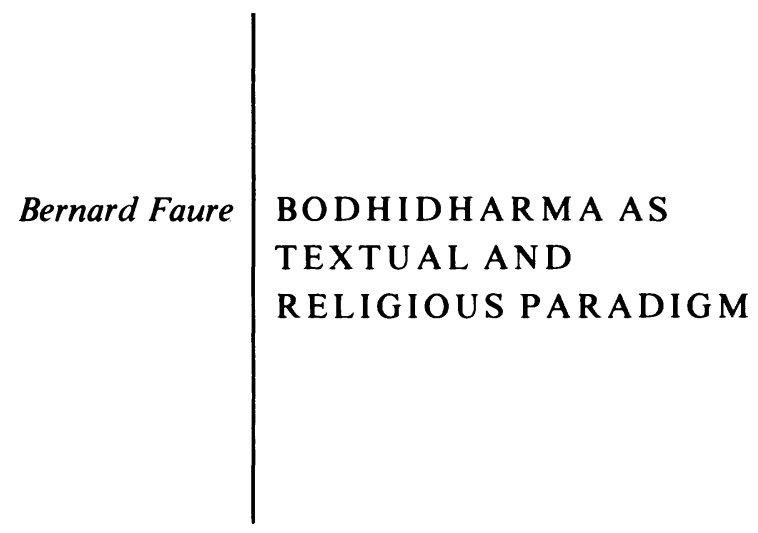

In the last few decades, the study of Ch'an or Zen Buddhism has progressed greatly due essentially to the rediscovery of the Tun-huang manuscripts and to the role of Chinese and Japanese scholars such as $\mathrm{Hu}$ Shih, Ui Hakuju, Sekiguchi Shindai, and Yanagida Seizan. These scholars have attempted to detach themselves from the sectarian affiliations that once dominated the field of Ch'an studies and to approach the history of this tradition from an objective point of view. We owe to them an understanding of Ch'an/Zen that is sometimes quite different from the traditional account exported to the West by D. T. Suzuki, which unfortunately too often still prevails. Despite Suzuki's lasting influence, the situation of Ch'an studies in the West is gradually changing, and the early Ch'an tradition in particular is being placed by some scholars in its proper historical context. ${ }^{1}$ This historical approach is certainly necessary and needs to be encouraged. But it also raises various problems, particularly in the case of the so-called founders of Ch'an schools. I would like to consider some of those problems here. Generally speaking, there are two alternatives to the historical approach: philosophical hermeneutics and structural criticism. I limit myself here to the structural approach and take

I See, e.g., Philip B. Yampolsky, The Platform Sutra of the Sixth Patriarch (New York: Columbia University Press, 1966).

- 1986 by The University of Chicago. All rights reserved. $0018-2710 / 86 / 2503-0005 \$ 01.00$ 
as an example the legendary founder of Ch'an, the Indian monk Bodhidharma.

POSITION OF THE PROBLEM: THE "BIOGRAPHICAL" ILLUSION

Bodhidharma's biography is very obscure, yet his life is relatively well known. This is less paradoxical than it may sound. I shall argue that hagiography flourishes precisely owing to the scarcity of historical materials. The main task of historians, usually, is to try to uncover the facts behind the legend. The texts concerning Bodhidharma are considered by historians as documents that need to be interpreted using the historical method so as to bring to light their hidden truths. Often enough, after this mortuary washing, only a skeleton remains, and it is this skeleton that will enter the museum of history. In fact, some missing bones may have to be taken from another skeleton to complete the exhibit. Indeed, though some may consider biography the opposite of hagiography, the biographical process is in most cases only an unconscious duplication of the hagiographical process. Both are characterized by an attitude that I would call "substantialist," in that they consider a personage as some kind of individual entity whose essence is reflected in specific texts-biographical or doctrinal.

Thus, we have many biographical notices concerning Bodhidharma and several works attributed to him. Sekiguchi Shindai has shown that most of these Treatises of Bodhidharma were apocryphal. ${ }^{2}$ Only one of them, the so-called Treatise on the Two Entrances and Four Practices, is presently considered to be Bodhidharma's teaching as recorded by his disciple T'an-lin. ${ }^{3}$ In this work is also found the first biographical notice concerning Bodhidharma. According to this account, he was a South Indian monk who came to China to transmit the essence of Mahāyāna teachings. After his arrival in Canton, he went to Lo-yang, then the capital of the Northern Wei. These biographical elements reappear in Tao-hsüan's Continued Biographies of Eminent Monks, written in 645 (and revised down to 664) more than one century after Bodhidharma's mysterious death. ${ }^{4}$ According to Tao-hsüan, Bodhidharma's type of practice, the so-called wall contemplation, was considerably different from and much more difficult to understand than the classical Indian dhyāna then prevalent in

2 Sekiguchi Shindai, Daruma daishi no kenkyū [A study of the great master Bodhidharma] (Tokyo: Shunjusha, 1957).

${ }^{3}$ See J. A. Jorgensen, "The Earliest Text of Ch'an Buddhism: The Long Scroll" (M.A. thesis, Australian National University, Canberra, 1979).

${ }^{4}$ See Taishō shinshū daizō $k y \bar{o}$ [Taishō edition of the Buddhist canon], ed. Takakusu Junjirō et al. (Tokyo: 1924-32), 50, 2060, 55lc (hereafter abbreviated as T.; the references give the volume number, the catalog number, and the page and column). 
Northern China. ${ }^{5}$ He therefore attracted only a few followers. Among them was Hui-k'o, who later became the second patriarch of Ch'an. A passage in Hui-k'o's notice tells us that Bodhidharma transmitted to him a Buddhist scripture, the Lañkāvatāra-sūtra, as the essence of his teaching; ${ }^{6}$ hence the Ch'an school was first known as the "Lankāvatāra School." Another earlier mention of Bodhidharma is to be found in the Record of the Buddhist Monasteries of Lo-yang. ${ }^{7}$ In this text, Bodhidharma is presented as a very old Central Asian monk who spent several days singing in praise of the great stupa in the Yung-ning monastery.

After endless discussions, historians have harmonized these conflicting images of Bodhidharma - as a devout and somewhat senile monk, as an austere practitioner of some esoteric type of meditation, and as a transmitter of Buddhist scriptures - to give a coherent account of his personality that differs greatly from that of the legendary figure of the Ch'an tradition. Yet all these discussions and the subsequent conclusions may have missed the point. As I mentioned earlier, the historiographical process that leads to the elaboration of this biography bears important resemblances to the hagiographical process on which it relies. Both share the same obsession with filling the chronological gaps by borrowing from various sources, and both are therefore ideological products. By considering the texts as documents that will yield valuable information, historiography completely ignores their worklike nature. ${ }^{8}$ Such an easy division between "historical" and "hagiographical" components does violence to the texts and deprives the historian of valuable information about the evolution of Ch'an thought. Historiographical discourse often assumes that the earliest sources are the most authentic without questioning that assumption. In other words it is a rather arbitrary reconstruction that ignores or hides its ideological motivations and simply "submits a literary genre to the laws of another-historiography." In the case of Ch'an historiography, a teleological conception of history appears to hold sway, one which takes classical Japanese Zen as the logical end of the Ch'an tradition, which in turn makes the "search for the real

5 T. 50, 2060, 596c.

6 T. 50, 2060, 552b.

7 See A. C. Soper, Literary Evidence for Early Buddhist Art in China, Artibus Asiae, suppl. 19 (Ascona, Switzerland: Artibus Asiae Publishers, n.d.), p. 111; see also Paul Pelliot, "Notes sur quelques artistes des Six Dynasties et des T'ang," T'oung Pao 22 (1923): 253-61.

8 On the distinction between the documentary and "worklike" aspects of a text, see Dominick Lacapra, Rethinking Intellectual History: Texts, Contexts, Language (Ithaca, N.Y.: Cornell University Press, 1983), p. 30.

9 Michel de Certeau, L'écriture de l'histoire (Paris: Gallimard, 1975), p. 275. 
Bodhidharma" meaningful only as a legitimation of the Zen tradition. If Bodhidharma was no more than an ordinary Central Asian monk, we may as well dismiss him as irrelevant to an understanding of the Ch'an and later Zen traditions. Bodhidharma does not, then, deserve attention as a historical person; and Buddhist historiographers should perhaps stop searching for "eminent monks" and writing their "biographies." The biographies that exist already have literary but not historical value; Bodhidharma should be interpreted as a textual and religious paradigm and not be reconstructed as a historical figure or a psychological essence.

But one may object that we possess works attributed to Bodhidharma and that his thought, at least, is relatively well known to us. Here again, we may be misled by thinking that is too "substantialist." As a working hypothesis Michel Foucault's definition of the author might yield much better results. According to Foucault, "The author is the principle of thrift in the proliferation of meaning. ... [He] is not an indefinite source of significations which fill the work; he is a certain functional principle by which, in our culture, one limits, excludes and chooses; in short, by which one impedes the free circulation, the free manipulation, the free composition, decomposition and recomposition of fictions." 10

Such a redefinition of the author may help us avoid the type of historicist reductionism that can still be found in very recent Ch'an studies. In one such study, for example, we find an attempt at reconstructing the thought of the dhyanna master Seng-ch'ou (480-560), the contemporary and successful rival of Bodhidharma (according to Tao-hsüan's Continued Biographies). ${ }^{11}$ Seng-ch'ou is credited with a number of works that are clearly the products of a much later period and reflect the point of view of the so-called Northern School of Ch'an. ${ }^{12}$ The same type of reductionism is found in the study of eminent Ch'an monks such as Wo-lun, ${ }^{13}$ Shen-hsiu, or Hui-neng. ${ }^{14}$ This traditional discussion of authorship is reminiscent of Borges's fiction about the world of Tlön, in which all books are considered

10 See Michel Foucault, "What Is an Author?" in Textual Strategies: Perspectives in Post-structuralist Criticism, ed. Josue V. Harari (Ithaca, N.Y.: Cornell University Press, 1979), p. 159.

11 T. 50, 2060, 553b.

12 See Jan Yün-hua, "Seng-ch'ou's Method of Dhyāna," in Early Ch'an in China and Tibet, ed. Lewis Lancaster and Whalen Lai (Berkeley and Los Angeles: University of California Press, 1983), pp. 54-63.

${ }^{13}$ See Wu Chi-yü, "Wo-lun ch'an-shih i-yü Tun-huang T'u-fan-wen (Pelliot 116 hao) i-pen k’ao-shih," Tung-huang hsüeh 4 (1979): 33-46.

14 This may be equally true in the case of Bodhidharma's Treatise on the Two Entrances, which is strongly reminiscent of Seng-ch'ou's Hsin-hsing lun [Treatise on mental practice]. 
the work of a single author: "The critics often invent authors: they select two dissimilar works - the Tao-te ching and the 1001 Nights, say-attribute them to the same writer and then determine most scrupulously the psychology of this interesting homme de lettres." 15 As the literary critic Gérard Genette points out, "Fundamentally, Tlönian criticism is not the contrary of our positivist criticism, it is rather its hyperbole." 16

\section{STRUCTURAL ANALYSIS}

I would therefore like to treat Bodhidharma's "life" as a literary piece belonging to the genre of hagiography. The first step toward understanding its meaning, then, is to ask what this genre is and by what rules it is governed. In other words, what is its syntagmatic structure (i.e., "the actual link between various functions in a given text")? ${ }^{17}$ Michel de Certeau has proposed an answer worth considering, namely, that "hagiography is characterized by a predominance of precisions concerning places over precisions concerning time... . The life of a saint is a composition of places." 18

The second step is to examine the paradigmatic structure of the hagiographical text (i.e., "the virtual relations between analogous or opposed functions, from one text to the other, in the whole corpus under consideration"). This leads me to ask whether the meaning of the hagiographical text itself has ever been fixed once for all. According to Ferdinand de Saussure: "To imagine that a legend begins with a meaning, has had since its first origin the meaning that it now has, is an operation beyond my understanding. It seems to suppose really that there have never been any material elements transmitted on this legend through centuries." 19

De Saussure contends that in any particular legend each of the characters "is a symbol for which one can observe variations of: (a) name, (b) position vis-à-vis others, (c) character, and (d) function and actions. If a name is transposed, it could follow that part of the action is reciprocally transposed or that the whole drama is entirely changed by an accident of this kind." 20

This, I believe, can provide a good starting point from which to examine Bodhidharma's life as a narrative. It is, in a sense, more

15 Jorge Luis Borges, Labyrinths (New York: New Directions, 1964), p. 13.

16 Gérard Genette, Figures I (Paris: Seuil, 1966), p. 129.

17 Ibid., p. 154.

18 Certeau, p. 286.

19 See Jean Starobinski, Words upon Words: The Anagrams of Ferdinand de Saussure (New Haven, Conn.: Yale University Press, 1979), p. 8.

20 Ibid., pp. 5-6. 
flexible than Vladimir Propp's theories concerning the folktale, ${ }^{21}$ which do not take into consideration the semantic value of the hero's name and are somewhat too systematic for our purpose. The same may be said of Roland Barthes's and Claude Bremond's attempts at analyzing the logic of the narrative, not to mention Lévi-Strauss's study of mythology. ${ }^{22}$ Hagiography is a hybrid type of narrative that offers more resistance to structural analysis than the folktale or the myth; yet recent developments in the field of textual analysis may still yield significant results.

\section{A}

Let us reconsider Bodhidharma's life in the light of de Saussure's definition by focusing on two of its elements, the function and the name. In the Continued Biographies of Eminent Monks, Bodhidharma is contrasted with the dhyanna master Seng-ch'ou, whose method of meditation, although deemed of a rather inferior type, was quite popular. To quote Tao-hsüan: "Thus, when we look at these two tenets [of Seng-ch'ou and Bodhidharma, it is clear that] they are like the two wheels of the same cart. [Seng-] ch'ou embraced the [practice called] the 'foundations of mindfulness', a model of purity to be venerated. Bodhidharma relied on the teaching of emptiness, whose purport is obscure and deep. Due to this fact, his principle was intrinsically difficult to comprehend, while Seng-ch'ou's model was easily accessible." ${ }^{23}$

This contrast is a typical literary device, and the opposition between the two men was probably not so clear cut. It is reminiscent of another famous antagonism, that of the respective founders of the so-called Northern and Southern schools of Ch'an, Shen-hsiu and Hui-neng, ${ }^{24}$ who became paradigms of the two main types of Ch'an practitioners. Any later Ch'an monk was, in a way, a Hui-neng or a Shen-hsiu. Again, it is clear that the contrast between the two has been exaggerated for hagiographical purposes.

But, more than the contrast itself, what I would like to stress is that, in the early Ch'an tradition, both Bodhidharma and Seng-ch'ou, or Hui-neng and Shen-Hsiu, are symmetrical figures that imply each

21 Vladimir Propp, Morphology of the Folktale (Bloomington: Indiana University Research Center in Anthropology, Folklore and Linguistics, 1968).

22 Roland Barthes, "Introduction to the Structural Analysis of Narratives," in ImageMusic-Text (New York: Hill \& Wang, 1977); Claude Bremond, Logique du récit (Paris: Seuil, 1973); Claude Lévi-Strauss, Structural Anthropology, 2 vols. (New York: Basic Books, 1963-76).

${ }^{23}$ T. 50, 2060, 596c.

24 Yampolsky (n. l above), pp. 130-32. 
other. They constitute a narrative "actor," to use Terence Turner's terminology. According to Turner, "An 'actor' may become polarized into two contrasting figures, sharing one attribute but opposed upon one or more others." ${ }^{25}$ The text is a whole, and the literary device used clearly affects the account of the life of each protagonist. It may therefore be artificial to dissect this kind of "biography" and to keep only what concerns Bodhidharma or Seng-ch'ou. Furthermore, the polarization between the two figures might be more than a simple literary device and might reflect instead a preexistent connection at the level of popular consciousness. ${ }^{26}$

Another possible model is provided by Barthes's hypothesis that many narratives "set two adversaries in conflict over some stake; the subject is then truly double, not reducible further by substitution; indeed, this is even perhaps a common archaic form, as though narrative, after the fashion of certain languages, had also known a dual of persons." 27 (Note that the French word duel has both meanings of "duel" or contest, and "dual" [the category in Greek grammar intermediate between singular and plural].) One of the protagonists of the duel (contrast or conflict) may change, but the duel itself remains. Thus, the contrast between Bodhidharma and Seng-ch'ou is structurally analogous to the rivalry between Hui-neng and Shen-hsiu, which is its sectarian hyperbole. It reflects the opposition and complementarity between the two levels of truth (absolute and conventional) or, in Zen terminology, between the theories of kyōge betsuden (special transmission outside of the Scriptures) and kyōzen itchi (harmony between Zen and the Scriptures), that is, between purity and eclecticism.

The syntagmatic contrast between Bodhidharma and Seng-ch'ou is obvious from Tao-hsüan's notice. The paradigmatic equivalence between them can be found in the fact that to both are attributed parallel theories concerning the "two entrances" and that both were considered candidates for the position of "first patriarch" by the early Ch'an school. Both, in de Saussure's terms, have the same function in Ch'an discourse and legend, where they are represented as Taoist immortals, Bodhidharma achieving immortality through the so-called

25 Terence Turner, "Narrative Structure and Mythopoiesis," Arethusa 10, no. 1 (1977): 155.

26 We may think here of what René Girard, in his book on Violence and the Sacred (Baltimore: Johns Hopkins University Press, 1977), has said about "antagonistic mimesis" and the scapegoating process leading to the eviction of the double, later glorified as a "founder." Bodhidharma's death remains mysterious, and some Japanese scholars have suggested that he may even have been executed. The legend tells us that he was poisoned by jealous rivals.

27 Barthes, p. 108. 
deliverance from the corpse, Seng-ch'ou manifesting his supernatural powers by taming two tigers and causing the welling up of a "divine source." 28 Thus, Seng-ch'ou appears as the main double of Bodhidharma: on the syntagmatic axis of the hagiographical narrative, he is a rival, on its paradigmatic axis, he is a substitute. ${ }^{29}$ Both Seng-ch'ou and Bodhidharma were apparently regarded by Ching-chüeh, the author of the Leng-ch'ieh shih-tzu chi, as the patriarchs of the two main trends of early Ch'an. ${ }^{30}$ The amalgam between the two figures was achieved around the same time, as we can infer from a poem by Ts'en Chen (715-70) about a foreign monk who concentrated on the Lañkāvatāra-sūtra and who had subdued two tigers and a dragon (an allusion to the "divine source" kept by a dragon). ${ }^{31}$

On the paradigmatic axis of Bodhidharma's hagiography, we find legends related to other thaumaturges such as Pao-chih and Fu "the Mahasattva" (alias Fu Hsi). Both characters served as models for a certain trend in Buddhism that considered dhyāna as a way to acquire supernatural powers. Fu Hsi (497-569), the "Chinese Vimalakīrti," is also considered as the precursor of the T'ien-t'ai school (as is Sengch'ou). The famous meeting between Bodhidharma and the Liang emperor Wu (another typical example of "duel") ${ }^{32}$ is a variant of the encounter between $\mathrm{Fu} \mathrm{Hsi}$ and this emperor. ${ }^{33}$ In both cases, Paochih plays the role of a clairvoyant witness who reveals to the perplexed emperor the real identity of his interlocutor ( Fu Hsi being a manifestation of the future Buddha Maitreya, Bodhidharma an avatar of the Bodhisattva Avalokiteśvara [Chinese Kuan-yin]).

The similar function played by Fu Hsi and Bodhidharma is reflected in the comment by the T'ien-t'ai monk Chan-jan that the "Incarnation from Tușita Heaven" (Fu Hsi as Maitreya) surpasses the "coming of the Indian saint," ${ }^{34}$ which is to say, T'ien-t'ai teaching is superior to

${ }^{28}$ See Yanagida Seizan, Shoki Zenshū shisho no kenkyū [A study of the historiographical works of the early Ch'an school] (Kyoto: Hōzōkan, 1967), p. 597. The names of Bodhidharma and Hui-neng are also related to similar "divine sources," and the latter is known in the legend as a "dragon-subduer." See Michel Soymié, "Sources et sourciers en Chine," Bulletin de la Maison franco-japonaise, n.s., 7, no. 1 (1952): 33-34.

29 The same could be said in the case of Hui-neng and Seng-ch'ou, who are at the same time rivals in the narrative (syntagmatic axis) and functional equivalents (paradigmatic axis) as "sixth patriarch" of the early Ch'an tradition.

30 T. 85, 2837, 1284c; and Yanagida, p. 518.

${ }^{31}$ See "T'ai-po hu-seng ko" [Song of the barbarian monk of T'ai-po], in Ch'üan T'ang shih, chüan 199, ed. Sheng Tsu (Taipei: Hung-ye shu chü, 1977), 1:2057 ff.

32 See Pi-yen lu [The record of the blue cliff], "case" I (T. 48, 2003, 140a).

33 Ibid., "case" 67 (T. 48, 2003, 197a).

34 See Chih-kuan i-li $(T .46,1913,452 \mathrm{c})$. 
Ch'an. ${ }^{35}$ The logic at work here is clearly a sectarian one. But the sectarian interpretation does not do justice to the dynamism and complexity of the legend.

\section{B}

If we consider now the role played by the name of Bodhidharma in the evolution of his legend, we come to an even more complex situation. The substitution of names is, according to de Saussure, one of the "two types of historic modification of legend which might well be considered the most difficult to accept." ${ }^{36}$

The most obvious confusion is the one between Bodhidharma and the Kashmirian monk Dharmatrāta (who flourished in the beginning of the fifth century), to whom was (unduly) attributed a dhyāna-sūtra (Ta-mo-to-lo ch'an ching). Not only has Dharmatrāta's lineage become Bodhidharma's lineage, and the basis of the later Ch'an patriarchal tradition, but Bodhidharma himself has become known in Tibet as Bodhidharmatrāta. ${ }^{37}$ Note that, in the Tibetan tradition, he has become, with the Northern Ch'an master Mahāyāna, one of the two characters added to the list of the eighteen arhats. ${ }^{38}$ Not too surprisingly, Mahāyāna himself is represented as accompanied by a tiger, a possible resurgence of the Seng-ch'ou figure. ${ }^{39}$

35 This polemical attitude is the product of a later period, but the relationships between T'ien-t'ai and Ch'an schools have also given birth to the legend of the encounter between Bodhidharma and Nan-yüeh Hui-ssu (the first patriarch of T'ient'ai). Hui-ssu becomes a disciple of the Indian monk, who tells him that both will be later reincarnated in Japan (see Kōjō's Isshinkaimon, T. 74, 2379, 653b). This legend eventually merges with the story of the Japanese prince Shōtoku (himself considered as a reincarnation of Hui-ssu) meeting a starving beggar on the roadside and exchanging poems with this strange apparition in which he has recognized his former master Bodhidharma $(T .74,2379,653 \mathrm{c})$. Another legendary encounter is the one between Bodhidharma and Chih-i, the actual founder of the T'ien-t'ai school. The story is found in a fourteenth-century Tendai encyclopedia, the Keiran $\operatorname{sh} \bar{u} y \bar{o} \operatorname{sh} \bar{u}(T .76,2410,532 \mathrm{~b})$ and reveals the same opposition between kyōge betsuden and kyōzen itchi.

36 The other is "a change of motive or aim for an action which remains unchanged" (see Starobinski [n. 19 above], p. 7).

37 See Paul Demiéville, “Appendice sur 'Damoduolo' (Dharmatrā[ta])," in Jao Tsong-yi et al., Peintures monochromes de Tun-huang (Dunhuang baihua), Mémoires archéologiques, vol. 13, no. 1 (Paris: Ecole Française d'Extrême-Orient, 1978), pp. 43-49.

38 On the question of the sixteen or eighteen disciples of Buddha, see Sylvain Lévi and Edouard Chavannes, "Les seize arhats protecteurs de la Loi," Journal Asiatique 8 (1916): 5-50, 189-304; M. W. de Visser, The Arhats in China and Japan (Berlin: Oesterheld, 1923).

39 There is also some confusion in the iconography with the Chinese translator Hsüan-tsang and Seng-ch'ou. See Yamaguchi Zuihō, "Tora wo tomonau daijūhachi rakanzu no raireki" [On the origins of the eighteenth arhat], Indo koten kenky $\bar{u} 6$ (May 1984): 392-422. 
Bodhidharma's name appears sometimes truncated as Bodhi, or more often as Dharma (Ta-mo). In the first case, it may be confused with another of his rivals, Bodhiruci. Incidentally, Bodhiruci (d. 527) was a translator of the Lañkāvatāra-sūtra, in a recension different from the one supposedly transmitted by Bodhidharma to his disciple Hui-k'o. According to the legend, Bodhiruci and another monk, Kuang-t'ung, jealous of Bodhidharma's fame, tried to poison him several times and eventually succeeded. ${ }^{40}$ Kuang-t'ung (alias Huikuang, 468-537) was himself a disciple of Seng-ch'ou and had also studied on Mount Sung at the famous Shao-lin monastery. This monastery had been built by the emperor Hsiao-wen of the Northern Wei for another Central Asian monk named Fo-t'o or Pa-t'o (Chinese transcription for Buddha or Bhadra). ${ }^{41}$ It is only much later, due to specific historical circumstances into which I cannot enter now, that Bodhidharma's name came to be associated with the Shao-lin monastery, leading him to become the posthumous founder of the martial art known as "Shao-lin boxing" (Shörinji kempō). From the Sung-shan gazetteers, ${ }^{42}$ we can assume that there was an apparent amalgamation of the lineages of Fo-t'o/Seng-ch'ou and of Bodhidharma/Hui-k'o. Bodhidharma comes to play the same role as Buddha (or Bhadra) as the patriarch of the Shao-lin ssu.

Pa-t'o is also the abbreviated transcription used for Gunabhadra (394-468), the first translator of the Lañkāvatāra-sūtra. Gunabhadra's translation is precisely the recension transmitted by Bodhidharma to Hui-k'o. In the Leng-ch'ieh shih-tzu chi, ${ }^{43}$ Gunabhadra is presented as the master of Bodhidharma, and this biographical interpolation may result from his role as transmitter of the Lankāvatāra-sūtra or from a confusion among the founder of the Shao-lin monastery, the dhyāna master Pa-t'o, and Bodhidharma's hypothetical nine years' practice near this monastery. In a later work of the Lañkāvatāra tradition, ${ }^{44}$ the relationship between Gunabhadra and Bodhidharma is inverted, and Bodhidharma becomes the master of Gunabhadra. In any case, the dual/duel structure remains.

Thus the different elements of the legend discerned by de Saussure reinforce each other and are in fact rather difficult to distinguish.

40 The story first appears in an eighth-century work, the Li-tai fa-pao chi (T. 51, 2075, 180c).

41 Concerning this monk, see Pelliot (n. 7 above), pp. 262-64.

42 See, e.g., Tung Kao, Ch'üan T'ang wen, chüan 514 (Taipei: Hua-wen shu chü, 1965), 11:6619.

${ }^{43}$ T. 85, 2837, 1284c.

44 See the Leng-ch'ieh ching ch'an-men hsi-t'an chang (T. 85, 2779, 536a); and Paul Demiéville and Jao Tsong-yi, Airs de Touen-houang (Touen-houang $\left.k^{\prime \prime} i u\right):$ Airs $\grave{a}$ chanter des VIIle-Xe siècles (Paris: CNRS, 1971), pp. 86-87. 
However inconclusive or impressionistic this argument may seem, all these clues point toward the same conclusion: Bodhidharma's life is a hybrid textual construction, and it is only a part of a larger structure that is also at work in the lives of masters apparently as different as Seng-ch'ou, Pao-chih, Fu Hsi, Fo-t'o (Pa-t'o), Guṇabhadra, Bodhiruci, et cetera. All these characters, before being historical figures, are textual paradigms. Their meaning is not primarily in their historicity but in the significant modifications achieved by their legends.

But biographies, however hagiographic they may be, are not simply legends or myths and are more resistant to a structural analysis than the latter genre. The approach we have taken here cannot be applied indiscriminately. It will prove most useful with certain categories of traditional figures, the so-called founders of a school or the representatives of certain trends. Significantly, most founders have a very dim historical existence. Most of the Buddhist schools start in relative obscurity and are organized by a second- or third-generation successor, who, I would argue, is in most cases the real founder. The first patriarch is retrospectively promoted to his honorific rank in order to give more legitimacy to the new school. He serves as a blank space on which one may project all the necessary "biographical" elements. In other words, there is no real origin to the patriarchal tradition, no real "founder." The character who plays that role is, to use LéviStrauss's expression concerning myth, a "virtual focus," a virtual object whose shadow alone is real. ${ }^{45}$ His "biography" will proliferate around this obscure source, and historical details will soon turn into legend.

Besides that of Bodhidharma, other well-known embellished biographies are the lives of the so-called third and sixth patriarchs of the Ch'an tradition, Seng-ts'an and Hui-neng. In fact, they may have provided the missing links in the patriarchal lineage. The main purpose of this lineage itself was to link artificially several different schools. The first school, called the "School of Bodhidharma," originated probably with Hui-k'o or with a later Lañkāvatāra master named Fa-ch'ung (587-665?). The second school, the so-called Tungshan or Eastern Mountain School, was founded by the "fourth patriarch" Tao-hsin (580-651) and drew its legitimacy from the obscure figure of Seng-ts'an. The first detailed biographical account concerning the future "third patriarch" is to be found in the Leng-ch"ieh shihtzu chi. The third school, the so-called Southern School, originated

45 Claude Lévi-Strauss, The Raw and the Cooked (New York: Harper \& Row, 1969), p. 5 . 
with Shen-hui (684-758) and not, as the tradition would have us believe, with Hui-neng, whose chief merit was to be relatively unknown. The lives of these three Ch'an masters (Bodhidharma, Sengts'an, and Hui-neng) are reconstructions dating from the eighth century, at a time when sectarianism was intense. ${ }^{46}$ Their purpose is largely ideological. In the same way, the "classical" Ch'an of the ninth century traces its source back to two unknown disciples of Hui-neng, Nan-yüeh Huai-jang and Ch'ing-yüan Hsing-ssu. Being fundamentally paradigms for orthodox practice, these Ch'an masters should be treated as such and not given a false psychological identity through misguided erudition. This means that all variants of a hagiographical topos should first be considered in a synchronic perspective, without trying to sort out the historical kernel from the shell of legend. This metaphor of shell and kernel, implicit in the work of most historians, should itself be questioned. By thus widening the scope of our study and abandoning - at least for the founding figures - the obsolete concept of historical individuality, we might get closer to the global structure that regulates the transformations of actual biographies.

But this may not suffice to explain why we get, for example, the type called Bodhidharma as the first patriarch of Ch'an, instead of other possible types such as Seng-ch'ou or Fu Hsi. It seems that we have to reintroduce the historical or diachronic dimension in the last resort in order to make sense of these apparent contingencies. To interpret hybrid texts, our method must be itself hybrid. Although it will stress a kind of structural analysis, it must be aware of the failure of all systems that claim in their perfection to transcend history. Only by rejecting all methodological extremes, in a typical Buddhist fashion, may we reach a new, although limited, understanding of "the meaning of Bodhidharma's coming from the West."

\section{Cornell University}

46 On the formation of these legends, see Yampolsky (n. 1 above), pp. 3-88. 